\title{
PENGARUH EKSTRAK LOMPONG MENTAH ( Colocasia esculenta L Schoot) TERHADAP AKTIVITAS FAGOSITOSIS DAN KADAR NO (NITRIT OKSIDA) MENCIT BALB/C SEBELUM DAN SESUDAH TERINFEKSI LISTERIA MONOCYTOGENES
}

\author{
Ria Purnawian Sulistiani, Hesti Murwani Rahayuningsih*)
}

Program Studi Ilmu Gizi Fakultas Kedokteran Universitas Diponegoro

J1.Dr.Sutomo No.18, Semarang, Telp (024) 8453708, Email : gizifk@ undip.ac.id

\begin{abstract}
Background: The leaves and stems of lompong (Colocasia esculenta L.Schoot) have been proven to have health benefits. Raw lompong extract provides protection and recovery from infection. Flavonoid contained in raw lompong extract potentially acts as immunomodulatory in preventive and curative actions.

Objective: To analyze the effect of raw lompong extract on phagocytic activity and NO (nitric oxide) level before and after infected Listeria monocytogenes.

Methods: This study was true experimental with post-test only group design. The subjects of this study were 21 male Balb/c mice. Based on simple random sampling, they were divided into three groups: a control group (induced Listeria); P1 (treatment 1 ); P2 (treatment 2). Listeria was induced on the fourth day. The data were analyzed with the Indepedent t test.

Results: There was significant differences in phagocytic activity $(p=0.015)$ and NO level $(p=0.041)$ between group $P 2-K$. There was no significant effect raw lompong extract between group P1-K in phagocytic activity $(p=0.19)$ and NO level ( $p=0907)$. There was no significant difference in phagocytic activity between P1-P2 group $(p=0.66)$, but there was significant difference in NO level between P1-P2 group $(p=0.047)$.

Conclusion:: 13mg/20gBW dose of raw lompong extract has curative effect. Raw lompong extract affects the phagocytic activity of macrophages and NO level in Balb/c mice infected by Listeria monocytogenes.

Keywords :Colocasia esculenta L Schoot, phagocytic activity, NO level, Listeria monocytogenes.
\end{abstract}

\section{ABSTRAK}

Latar belakang :Daun dan batang lompong (Colocasia esculenta L.Schoot) terbukti memiliki manfaat terhadap kesehatan. Ekstrak lompong mentah dapat memberikan perlindungan dan pemulihan dari infeksi. Flavonoid yang terdapat pada ekstrak lompong mentah berpotensi sebagai immunomodulator baik pada tindakan preventif maupun kuratif.

Tujuan : Menganalisis pengaruh ekstrak lompong mentah terhadap aktivitas fagositosis dan kadar NO (Nitrit Oksida) sebelum dan sesudah terinfeksi Listeria monocytogenes.

Metode : Penelitian ini merupakan penelitian true experimental dengan post test only group design. Subyek penelitian ini adalah 21 ekor mencit Balb/c jantan. Secara simple random sampling dibagi menjadi tiga kelompok: kelompok kontrol (diinduksi Listeria monoctyogenes); P1 (Perlakuan sebelum terinfeksi); P2 (Perlakuan sesudah terinfeksi). Listeria diinduksipada hari keempat.Data dianalisis dengan Independent t test.

Hasil: Terdapat perbedaan yang bermakna aktivitas fagositosis $(p=0.015)$ dan kadar NO $(p=0.041)$ antara kelompok P2-K. Tidak terdapat pengaruh ekstrak lompong mentah yang bermakna pada kelompok P1-K terhadap aktivitas fagositosis $(p=0.19)$ dan kadar NO ( $p=0.907)$. Tidak terdapat perbedaan bermakna pada aktivitas fagositosis antara kelompok P1-P2 ( $p=0.66)$ namun terdapat perbedaan yang bermakna antara kadar NO pada kelompok P1-P2 $(p=0.047)$.

Simpulan :Ekstrak lompong mentah dengan dosis 13mg/20gBB memiliki efek kuratif. Ekstrak lompong mentah dapat mempengaruhi aktivitas fagositosis makrofag dan kadar NO pada mencit Balb/c yang diinfeksi Listeria monocytogenes.

Kata kunci: Colocasia esculenta L Schoot, Aktivitas Fagositosis, Kadar NO, Listeria monocytogenes.

\section{PENDAHULUAN}

Ekstrak lompong (Colocasia esculenta L. Schoot) mentah memiliki aktivitas antimicrobial, antihepatotoxic, dan antiinflammatory. Penelitian sebelumnya, ekstrak etanol daun dan batang lompong telah terbukti sebagai antidiabetes pada tikus yang diinduksi aloksan. Ekstrak lompong menurunkan gula darah melalui sekresi insulin pankreas maupun melalui peningkatan penyerapan glukosa. ${ }^{1}$

Manfaat kesehatan ekstrak lompong mentah karena kandungan senyawa fitokimia yang terdapat didalamnya. Senyawa fitokimia tersebut diantara lainnya yaitu senyawa flavonoid berupa orientin, isoorientin, isovitexin, vicenin-2, orientin 7-O-glucoside, leteolin 7-O-glucoside. Ekstrak lompong juga mengandung senyawa terpenoid dan

${ }^{*}$ Penulis Penanggungjawab 
anthocyanins seperti cyanidin-3-glucoside, pelargonidin-3-glucoside dan cyanidin-3rhamnoside yang terbukti memiliki aktivitas antioksidan. Saponin dan tanin juga terdapat pada ekstrak lompong mentah..$^{2-5}$

Peneliti ingin membuktikan potensi immunomodulator ekstrak lompong mentah dalam memicu respon imun tubuh. Respon imun tubuh akan muncul ketika ada infeksi yang bisa disebabkan dari bakteri, virus maupun jamur. Bakteri yang digunakan untuk memicu respon imun seluler yaitu bakteri intraseluler. Salah satu bakteri intraseluler yang sifatnya telah diketahui dengan baik salah satunya adalah Listeria monocytogenes. ${ }^{6}$ Makrofag akan bekerja sama dengan limfosit $\mathrm{T}$ untuk membunuh bakteri Listeria. Makrofag akan memfagosit bakteri Listeria melalui proses fagositosis, dan limfosit $\mathrm{T}$ akan menghasilkan sitokin IFN- $\gamma$, TNF- $\alpha$ dan memacu sel NK (Natural Killer). Sitokin-sitokin tersebut akan mengaktivasi makrofag untuk mensekresikan NOS (Nitrit Oxyde Syntase) sehingga akan terbentuk NO (Nitrit Oksida). NO (Nitrit Oksida) kemudian akan melisis bakteri Listeria. Salah satu respon imun tubuh dapat dilihat dari aktivitas fagositosis dan kadar $\mathrm{NO}^{7}$ Isolasi makrofag dilakukan pada bagian cairan peritonium karena pada bagian tersebut terdapat makrofag dalam jumlah yang besar. ${ }^{8}$ Berdasarkan hal tersebut, aktivitas fagositosis dan kadar NO dipilih peneliti untuk menilai respon imun. Penetapan besar dosis menggunakan dosis maksimal yang bisa dikonsumsi manusia dalam sehari kemudian dikonversi ke mencit, sehingga mendapatkan dosis sebesar $13 \mathrm{mg} / 20 \mathrm{gBB}$. Perlakuan kelompok dibedakan sebelum dan sesudah infeksi bertujuan untuk mengetahui kemampuan ekstrak lompong sebagai upaya preventif dan kuratif.

\section{METODE PENELITIAN}

Penelitian ini dilakukan di Laboratorium Parasitologi Fakultas Kedokteran Universitas Diponegoro Semarang. Pengujian dilakukan di Laboratorium Penelitian dan Pengujian Terpadu Universitas Gadjah Mada Yogyakarta. Penelitian dilakukan dalam kurun waktu 2 bulan. Jenis penelitian merupakan penelitian eksperimental dengan rancangan true experimental dengan post test only control group design. Sampel penelitian 21 ekor mencit dengan kriteria inklusi adalah mencit strain Balb/c, umur 10 minggu, berat badan
20-30 gram, jantan dan sehat, sedangkan kriteria eksklusinya adalah mencit sakit selama masa adaptasi dan mencit yang mati selama perlakuan.

Mencit diadaptasikan selama 1 minggu kemudian dibagi secara acak menjadi 3 kelompok. Kelompok K, mencit yang diinokulasi Listeria monocytogenes dan tidak mendapat ekstrak lompong mentah. Kelompok P1, mencit yang diinokulasi Listeria monocytogenes dan diberi ekstrak lompong mentah sebelum terinfeksi. Kelompok P2, mencit yang diinokulasi Listeria monocytogenes dan diberi ekstrak lompong mentah setelah terinfeksi.

Inokulasi Listeria monocytogenes dilakukan pada hari keempat dengan dosis $1 \times 10^{5} \mathrm{CFU}$. Kelompok P1 diberi ekstrak lompong mentah pada hari pertama sampai hari ketiga, kelompok P2 hanya diberi pakan standar. Setelah inokulasi, kelompok P1 hanya diberi pakan standar, dan kelompok P2 diberi ekstrak lompong hingga hari keenam. Pada hari ketujuh mencit dibunuh dan dilakukan pemeriksaan sampel, mencit dinarkose menggunakan kloroform. Bagian mencit yang diambil adalah cairan intraperitoneal, yang dicuci dengan larutan RPMI sebanyak 3 kali untuk mendapatkan makrofag. ${ }^{9}$

Pemeriksaan aktivitas fagositosis menggunakan partikel latex serta pemeriksaan NO menggunakan reagens Gries. ${ }^{10,11}$ Pemeriksaan NO, makrofag dikultur pada mikroplate well 96 sebanyak $2,5 \times 10^{6} \mathrm{sel} / \mathrm{ml}$ dan diinkubasi selama 24 jam pada suhu $37^{\circ} \mathrm{C}$ dengan kadar $\mathrm{CO}_{2} 5 \%$. Supernatan yang didapat dari hasil pengkulturan makrofag diperiksa kadar nitrit oksidanya menggunakan alat ELISA Reader dengan metode Griess. ${ }^{11}$

Data yang dikumpulkan adalah data primer dari perhitungan jumlah partikel latex yang difagosit makrofag, serta kadar NO didapat dari pembacaan hasil kadar nitrit oksida makrofag. Variabel bebas dalam penelitian ini adalah pemberian ekstrak lompong mentah dengan dosis yang digunakan $13 \mathrm{mg} / 20 \mathrm{gBB}$ dan induksi bakteri Listeria monocytogenes $1 \times 10^{5} \mathrm{CFU}$. Variabel tergantung berupa aktivitas fagositosis (jumlah partikel latex yang difagosit makrofag) dan kadar nitrit oksida yang diproduksi oleh makrofag dalam pengkulturan. Data yang didapatkan diuji normalitasnya menggunakan Uji Saphiro Wilk, data terdistribusi normal maka dilanjutkan dengan Independet $t$ test. 
21 mencit balb/c, usia 10 minggu. $\mathrm{BB} \pm 20 \mathrm{~g}$

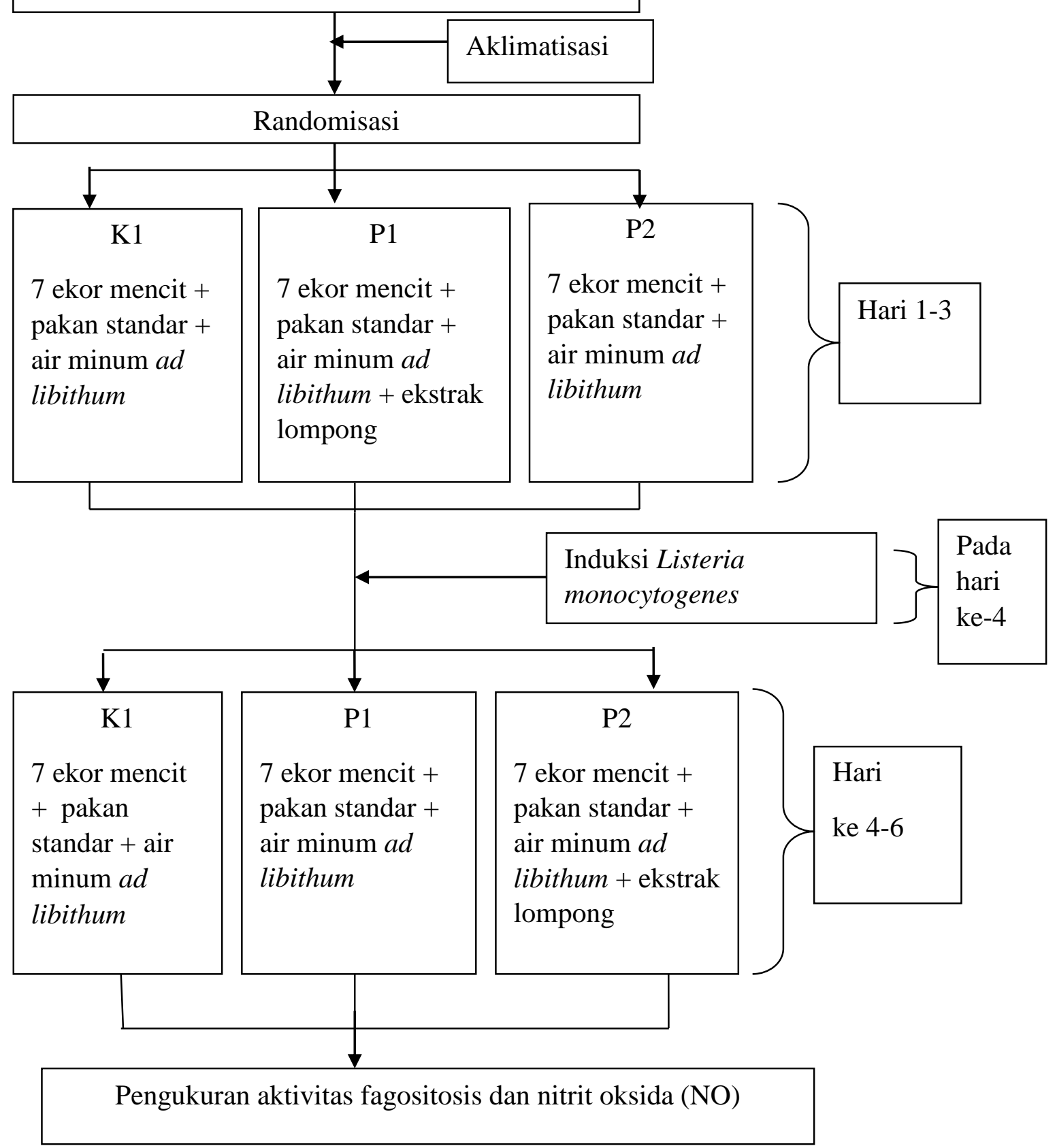

Gambar 1. Alur Kerja Penelitian

\section{HASIL \& PEMBAHASAN}

Penelitian tentang pengaruh ekstrak lompong mentah terhadap aktivitas fagositosis dan kadar nitrit oksida makrofag pada mencit Balb/c sebelum dan setelah terinfeksi Listeria monocytogenes telah dilakukan. Hasil penelitian berupa kemampuan fagositosis dengan menghitung indeks fagositosis makrofag dan kadar nitrit oksida dengan menggunakan metode Gries yang hasil reaksinya dibaca dengan menggunakan ELISA reader.

Data diuji normalitasnya dengan ShapiroWilk, dan didapatkan distribusi data yang tidak normal $(\mathrm{p}<0,05)$. Dilakukan proses transformasi data agar data tersebut berdistribusi normal, kemudian dilakukan Independet $t$ test. 
Tabel 1. Rerata aktivitas fagositosis dan Kadar NO

\begin{tabular}{|c|c|c|c|}
\hline & \multirow[b]{2}{*}{$\mathrm{n}$} & Aktivitas Fagositosis & Kadar NO \\
\hline & & Rerata $( \pm S D)$ & $\begin{array}{c}\text { Rerata }( \pm \text { SD }) \\
(\mu \mathrm{M})\end{array}$ \\
\hline $\mathrm{K}$ & 7 & $2.43( \pm 0.23)$ & $106.28( \pm 54.39)$ \\
\hline P1 & 7 & $3.15( \pm 1.29)$ & $102.43( \pm 66.41)$ \\
\hline $\mathrm{P} 2$ & 7 & $3.25( \pm 0.69)^{\mathrm{a}}$ & $183.71( \pm 71.04)^{\mathrm{b}}$ \\
\hline
\end{tabular}

$a=$ berbeda bermakna dengan kelompok kontrol $(p<0.05, p=0.015)$

$\mathrm{b}=$ berbeda bermakna dengan kelompok kontrol $(\mathrm{p}<0.05, \mathrm{p}=0.041)$

Tabel diatas menunjukan bahwa terjadi peningkatan rerata aktivitas fagositosis pada seluruh kelompok perlakuan dibandingkan kelompok kontrol. Terjadinya peningkatan aktivitas fagositosis dipicu oleh senyawa fitokimia yang terdapat dalam ekstrak lompong mentah. Senyawa fitokimia pada ekstrak lompong mentah diantara lain flavonoid, tanin, saponin dan phenol. ${ }^{3}$

Kelompok perlakuan dua lebih efektif meningkatkan aktivitas fagositosis daripada kelompok perlakuan satu. Dilihat dari jumlah rerata, rerata kelompok perlakuan dua juga memiliki jumlah rerata lebih tinggi. Ekstrak lompong mentah lebih efektif diberikan sesudah infeksi daripada sebelum terinfeksi. Pemberian ekstrak lompong mentah dengan dosis $13 \mathrm{mg} / 20 \mathrm{gBB}$ memiliki efek kuratif dapat mempengaruhi aktivitas fagositosis sehingga dapat dimanfaatkan untuk membantu pemulihan penyakit infeksi.

Pemberian ekstrak lompong mentah dengan dosis yang sama selama 3 hari secara statistik ternyata belum memiliki efek preventif namun tetap dapat meningkatkan aktivitas fagositosis dibanding kelompok kontrol. Peningkatan rerata indeks fagositosis pada semua kelompok perlakuan dibanding kelompok kontrol membuktikan bahwa ekstrak lompong mentah sebagai immunomodulator dapat merangsang kinerja makrofag.

Adanya pengaruh ekstrak lompong mentah terhadap aktivitas fagositosis disebabkan karena kandungan yang terdapat pada ekstrak lompong mentah. Sesuai dengan penelitian sebelumnya ekstrak lompong mentah mengandung flavonoid. ${ }^{12}$ Ekstrak lompong mentah mengandung $0.198 \%$ phenol, $0.261 \%$ tanin dan $0.88 \%$ flavonoid. Flavonoid memiliki efek anti tumor, antioksidan, immunostimulant, anti radang, analgesik, anti virus, anti fungi dan anti bakteri. Senyawa flavonoid telah terbukti dapat meningkatkan IL-2 dan proliferasi limfosit. ${ }^{13}$ Proliferasi limfosit akan mempengaruhi sel CD4+, yang akan menyebabkan sel Th1 teraktivasi. ${ }^{14}$ Sel Th1 yang telah teraktivasi akan mempengaruhi SMAF (Spesific Makrofag Activating Factor). SMAF (Spesific Makrofag Activating Factor) merupakan molekul-molekul multipel, salah satunya adalah IFN- $\gamma$. IFN- $\gamma$ (Interferon- $\gamma$ ) akan mengaktifkan makrofag, sehingga makrofag akan mengalami peningkatan aktivitas fagositosis. Hal ini akan menyebabkan makrofag dapat membunuh bakteri lebih cepat. ${ }^{15}$ Flavonoid juga memiliki mekanisme kerja dengan cara mengaktivasi sel NK untuk merangsang produksi IFN- $\gamma$. IFN- $\gamma$ (Interferon- $\gamma$ ) merupakan sitokin utama MAC (Macrophage Activating Cytokine) yang akan mengaktifkan makrofag dan memacu peningkatan aktivitas fagositosis. ${ }^{16}$

Makrofag dan neutrofil yang teraktivasi akan menghasilkan beberapa enzim proteolitik di phagolysosome yang berfungsi untuk mennghancurkan bakteri. Enzim tersebut diantaranya yaitu elastase dan cathepsin $G$. Beberapa reseptor seperti TLRs(Toll-like Receptors), $G$ protein-coupled receptors, antibody $F c$, complement $C 3$ dan sitokin IFN- $\gamma$ bekerjasama membunuh mikroba. ${ }^{7}$ Makrofag dan neutrofil akan mengkonversi molekul oksigen ke dalam ROS (Reactive Oxygen Species), dibantu dengan enzim IFN- $\gamma$ dan TLRs akan menghancurkan mikroba. Makrofag juga menghasilkan RNI (Reactive Nitrogen Intermediate) dibantu oleh enzim iNOS (inducible NO sintase) akan menghasilkan NO (Nitric Oxide). ${ }^{7}$

Meningkatnya respon imun selain dapat dilihat dari meningkatnya aktivitas fagositosis, juga dapat dilihat dari meningkatnya kadar NO (Nitrit Oksida). Kadar NO adalah jumlah NO yang terdapat pada supernatan kultur makrofag peritoneum. ${ }^{11}$ Hasil kadar NO menunjukkan rerata kadar NO pada kelompok perlakuan satu lebih rendah dibandingkan kelompok kontrol, sedangkan pada kelompok perlakuan dua lebih tinggi dibanding kelompok kontrol. Kadar NO pada kelompok perlakuan lebih rendah karena nitrit oksida bisa bersifat menjadi prooksidan. ${ }^{7}$

Hasil penelitian ini, didapatkan hasil bahwa ekstrak lompong mentah lebih efektif dimanfaatkan sebagai upaya kuratif daripada upaya preventif. Hasil ini sesuai dengan hipotesis penelitian karena pemberian ekstrak lompong mentah dengan dosis $13 \mathrm{mg} / 20 \mathrm{gBB}$ memiliki efek kuratif dapat 
mempengaruhi kadar NO. Hasil ini sesuai dengan penelitian sebelumnya, bahwa ekstrak lompong mentah dapat dimanfaatkan untuk membantu pemulihan penyakit infeksi. Namun, pemberian ekstrak dengan dosis yang sama selama 3 hari ternyata tidak memiliki efek preventif.

Kandungan ekstrak lompong mentah sebagai immunomodulator dapat meningkatkan respon imun. Respon imun tubuh yang diperlukan untuk melawan bakteri intraseluler adalah respon imun seluler. Salah satu respon imun seluler berupa produksi Nitrit Oksida (NO) oleh makrofag. ${ }^{12}$ Makrofag dapat diaktivasi oleh LPS (lipopolisakarida) bakteri, sel tubuh yang rusak, maupun oleh IFN- $\gamma$ (interferon gamma). Makrofag yang telah teraktivasi tersebut akan memakan bakteri intraseluler kemudian akan memproduksi, nitrit oksida (NO), lisosim, komplemen, hidrogen peroksida elastase dan kolagenase, IL-1, IL-12, IL10 , protrombin. ${ }^{12}$ Jika makrofag teraktivasi maka transkripsi gen yang menginduksi iNOS akan meningkat, sehingga akan menghasilkan NO dalam jumlah yang lebih banyak. NO akan berperan sebagai immunoregulator dan immunosupresif. ${ }^{17}$

Induksi Listeria pada kelompok yang diberi ekstrak lompong mentah setelah terinfeksi menunjukkan adanya peningkatan kadar NO dibandingkan kelompok kontrol. Induksi bakteri mengaktifkan sistem imun seluler mencit. Makrofag dan limfosit $\mathrm{T}$ saling bekerja sama untuk melawan bakteri Listeria. Limfosit $\mathrm{T}$ akan menghasilkan sitokin IFN- $\gamma$, TNF- $\alpha$ dan memacu sel NK (Natural Killer). Sitokin-sitokin tersebut akan mengaktivasi makrofag untuk mensekresikan NOS (Nitrit Oxyde Syntase) sehingga akan terbentuk NO (Nitrit Oksida). NO (Nitrit Oksida) kemudian akan melisis bakteri Listeria. ${ }^{7}$ Pemberian ekstrak lompong mentah dengan dosis $13 \mathrm{mg} / 20 \mathrm{gBB}$ mempengaruhi kadar NO. Hal ini juga menunjukkan bahwa kemampuan aktivitas makrofag dalam proses membunuh bakteri intraseluler juga meningkat sehingga ekstrak lompong mentah dapat digunakan sebagai upaya kuratif dalam melawan bakteri.
Listeria akan memicu produksi IL-2 serta akan akan mestimulasi sel NK dan $\mathrm{CD}^{+}$CTLs (Cytotoxic T Lymphocytes). ${ }^{18}$ IL-2 (Interleukin-2) merupakan sitokin yang biasa disebut hormon leukositotropik yang berfungsi sebagai stimulan proliferasi sel $\mathrm{B}$ dan sel $\mathrm{T}$. Sel $\mathrm{CD} 8^{+} \mathrm{CTL}$ merupakan sel $\mathrm{T}$ yang dapat mengenali peptida antigen dan mampu menginduksi kerusakan pada sel yang terinfeksi. Ketiganya akan mensekresikan IFN- $\gamma$ sehingga akan mengaktifkan makrofag. Makrofag tersebut kemudian memproduksi oksigen reaktif, menstimulasi produksi antibodi, dan mengopsonisasi bakteri. ${ }^{18}$

Sesuai dengan penelitian sebelumnya telah diketahui bahwa flavonoid meningkatkan produksi NO. ${ }^{19}$ Flavonoid selain memiliki efek immunostimulan juga memiliki efek immunosupresan, hal ini memungkinkan adanya penurunan kadar NO pada kelompok perlakuan. ${ }^{20}$ Flavonoid dapat meningkatkan stamina tubuh dengan cara meningkatkan sekresi endetol Nitrit Oksida Sintase (eNOS). Sekresi endetol Nitrit Oksida Sintase (eNOS) maka kadar NO akan meningkat juga. ${ }^{19}$ Tingginya kadar NO dapat berfungsi sebagai bakterisidal dan memiliki efek anti apopotosis. ${ }^{16}$ Mekanisme NO dalam meningkatkan imunitas seluler yaitu dengan meningkatkan kemampuannya sebagai zat sitotoksik dalam proses fagositosis. NO akan menggabungkan diri dengan $\mathrm{H}_{2} \mathrm{O}_{2}$ (hidrogen peroxside) atau superoxide sehingga membentuk radikal peroksinitrit yang sangat reaktif membunuh mikroba. $^{7}$

Ekstrak lompong mentah dapat dimanfaatkan untuk meningkatkan respon imun dan ekstrak lompong yang mengalami proses pemasakan pun juga memiliki manfaat yang sama. Ekstrak lompong dengan pengukusan 30 menit dan 45 menit memiliki nilai rerata indeks fagositosis dan kadar NO lebih tinggi dibanding kelompok kontrol. Kandungan phenol, tanin dan flavonoid, ekstrak lompong justru meningkat setelah mengalami proses pengukusan..$^{21,22}$

Tabel 2. Kandungan Ekstrak Lompong

\begin{tabular}{|c|c|c|c|}
\hline \multirow[b]{2}{*}{ Ekstrak } & \multicolumn{3}{|c|}{ Hasil Analisa } \\
\hline & $\begin{array}{c}\text { Phenol } \\
\%\end{array}$ & $\begin{array}{c}\text { Tanin } \\
\%\end{array}$ & $\begin{array}{c}\text { Flavonoid } \\
\%\end{array}$ \\
\hline Lompong mentah & 0.198 & 0.261 & 0.088 \\
\hline $\begin{array}{l}\text { Lompong dengan pengukusan } \\
\text { menit }\end{array}$ & 0.219 & 0.293 & 0.105 \\
\hline $\begin{array}{l}\text { Lompong dengan pengukusan } \\
\text { menit }\end{array}$ & 0.222 & 0.310 & 0.140 \\
\hline
\end{tabular}


Diketahui bahwa ekstrak lompong mentah dengan pengukusan 45 menit memiliki persentase kandungan phenol, tanin dan flavonoid tertinggi dibanding ekstrak lompong mentah dan ekstrak lompong dengan pengukusan 30 menit. $^{21,22}$ Kandungan senyawa fitokimia tersebut sebagai immunomodulator dapat memodulasi sistem imun tubuh dengan cara meningkatkan respon imun/ meningkatkan mekanisme pertahanan tubuh baik innate maupun adaptive serta dapat memberikan perlindungan terhadap patogen. Meningkatnya respon imun ditandai dengan meningkatnya kinerja makrofag dalam proses membunuh bakteri. ${ }^{7}$

Makrofag berfungsi memusnahkan bakteri/benda asing yang masuk ke dalam tubuh. Makrofag berperan dalam memfagositosis patogen dan menstimulasi limfosit dan sel imun untuk merespon patogen. Makrofag yang teraktivasi dapat diukur melalui aktivitas fagositosis dan kadar NO. ${ }^{12}$ Kinerja makrofag yang mengalami peningkatan akan disertai dengan peningkatan fagositosis. Pada fagositosis, fagosit yang aktif (makrofag dan neutrofil) akan mensekresikan nitrit oksida (NO). NO (Nitrit Oksida) juga bisa menyerang sel yang memproduksi dan sel yang berada disekitarnya sehingga memungkinkan terjadinya penurunan kadar NO meskipun aktivitas fagositosisnya tinggi. ${ }^{?}$

Listeria monocytogenes merupakan salah satu bakteri patogen intraseluler fakultatif sehingga tubuh membutuhkan mekanisme imunitas innate dan adaptive. Listeria akan mengaktifkan sel-sel NK dengan menstimulasi sel dendritik dan makrofag yang kemudian akan memproduksi IL-12. Sel-sel NK akan menghasilkan IFN- $\gamma$, IFN- $\gamma$ akan mengaktifkan makrofag dan memfagositosis bakteri. Sistem imun innate merupakan pertahanan awal terhadap bakteri, selanjutnya diperlukan mekanisme imunitas adaptive ( $T$ cell mediated immunity)/ imunitas seluler. ${ }^{6} \mathrm{Sel} \mathrm{CD}^{+}{ }^{+} \mathrm{T}$ dan sel $\mathrm{CD} 8{ }^{+} \mathrm{T}$ akan bekerja sama memberikan perlindungan terhadap bakteri intraseluler. Sel $\mathrm{CD}^{+}$akan menanggapi antigen melalui MHC II (Major Histocompatibility Complex II) dan berdiferensiasi menjadi effector $\mathrm{T}_{\mathrm{h}} 1$. Sel $\mathrm{T}_{\mathrm{h}}$ akan meningkatkan kemampuan fagosit dalam membunuh bakteri. Sel T akan mengekpresikan CD40 dan mensekresikan IFN- $\gamma$. Sel CD4+ Th1 mengaktifkan makrofag melalui sinyal yang diperantai interaksi CD40L-CD40 yang dilakukan oleh sitokin IFN- $\gamma .{ }^{22}$ Akibat dari sinyal CD40 dan IFN- $\gamma$ menyebabkan beberapa protein dalam makrofag meningkat. Sinyal CD40 akan mengaktifkan faktor transkripsi Nuclear Factor $\mathrm{\kappa B}$ (NF-KB) dan Activation Protein-1 (AP-1). IFN- $\gamma$ akan mengaktifkan faktor transkripsi STAT 1 (Signal Transducers and Activator of Transcription) dan IRF-1 (Interferon Response Factor-1). Sinyal tersebut akan meningkatkan jumlah protein yang bertanggung jawab sebagai efektor di CMI (Cell Mediated Immunity) sehingga makrofag akan memproduksi beberapa zat microbicidal, seperti ROS (Reactive Oxygen Species), NO dan enzim lisosom. ${ }^{23}$ Sel $\mathrm{CD}^{+} \mathrm{T}$ helper akan mensekresikan sitokin IL-2. Di sisi lain $\mathrm{CD}^{+} \mathrm{T}$ menanggapi antigen melalui MHC I dan akan bekerja jika bakteri yang terdapat pada fagolisosom masuk ke dalam sitosol, maka $\mathrm{CD} 8^{+} \mathrm{T}$ akan berproliferasi dan berdiferensiasi menjadi CTLs untuk melisis bakteri intraseluler di sitoplasma. Terdapat dua mekanisme CTLs dalam melisis bakteri. Mekanisme pertama, CTLs akan mengeluarkan enzim granzyme dan perforin kemudian menginduksi apoptosis. Mekanisme yang kedua yaitu CTLs akan mengekspresikan FasL ( Fas Ligan) kemudian menginduksi apoptosis. Sel $\mathrm{CD} 4^{+} \mathrm{T}$ dan $\mathrm{CD}^{+} \mathrm{T}$ bekerjasama untuk memberikan perlindungan terhadap bakteri Listeria monocytogenes. ${ }^{6,18}$

Respon imun selain dipengaruhi oleh infeksi (bakteri, jamur, virus), juga dipengaruhi oleh usia, asupan/status gizi, faktor stress dan sistem endokrin. ${ }^{24}$ Faktor-faktor tersebut pada penelitian ini dikendalikan, hanya saja untuk asupan tidak dilakukan pemantauan jumlah asupan per subjek tiap harinya. Data penelitian ini hanya terbatas pada pengukuran berat badan untuk menentukan dosis intervensi.

\section{SIMPULAN}

Pemberian ekstrak lompong (Colocasia esculenta L Schoot) mentah pada mencit Balb/c sebelum diinfeksi Listeria monocytogenes dapat meningkatkan rerata indeks fagositosis namun tidak berpengaruh secara bermakna terhadap aktivitas fagositosis makrofag. Pemberian ekstrak lompong mentah sesudah diinfeksi Listeria monocytogenes dapat meningkatkan aktivitas fagositosis makrofag. Pengaruh ekstrak lompong mentah terhadap aktivitas fagositosis lebih efektif apabila ekstrak lompong mentah diberikan sesudah terinfeksi, dimanfaatkan sebagai upaya kuratif.

Pemberian ekstrak lompong mentah sebelum diinfeksi Listeria monocytogenes memiliki rerata kadar NO (Nitrit Oksida) lebih rendah dibanding kelompok kontrol karena NO bersifat prooksidan. Pemberian ekstrak lompong mentah sesudah diinfeksi Listeria monocytogenes dapat meningkatkan kadar NO. Pengaruh ekstrak lompong mentah terhadap kadar NO lebih efektif 
apabila ekstrak lompong mentah diberikan sesudah terinfeksi, dimanfaatkan sebagai upaya kuratif.

\section{DAFTAR PUSTAKA}

1. Saha S, Rahmatullah M. Antihyperglicemic and Antinociceptive Activities Of Methanolic Extract of Colocasia esculenta (L.) Schoot Stems: a preliminary study. Advanced in Natural and Applied Sciences.2013.7(3);232-237.

2. Pereira PR, Aguila EMD, Verricimo MA, Zingali RB, Paschoalin VMF, Silva JT. Purification and Characterization of the Lectin from Taro (Colocasia esculenta) and its Effect on Mouse Splenocyte Proliferation In Vitro and In Vivo. Protein J. Springer. 2014;33: 92-99.

3. Halligudi N. Pharmalogical Potential of Colocasia an Edible Plant. Journal of Drug Discovery and Therapeutics. 2013; 1 (2):05-09

4. Agyarea C, Asaseb A, Lechtenbergc M, Niehuesc M, Detersc A, Henselc A. An Ethnopharmacological Survey And In Vitro Confirmation Of Ethnopharmacological Use Of Medicinal Plants Used For Wound Healing In Bosomtwi-Atwima-Kwanwoma Area, Ghana. Journal Of Ethnopharmacology.2009: 125, 393403.

5. Goncalves. Influence of Taro (Colocasia Esculenta L. Shott) Growth Conditions On The Phenolic Composition and Biological Properties. Elsevier. Food Chemistry. 2013; 141: 3480-3485.

6. Abbas AK, Lichtman AH, Shiv Pillai. Celullar And Molecular Immunology. 6th edition. Saunders elsevier; 2009: 355-360

7. Abbas AK, Lichtman AH, Shiv Pillai. Celullar And Molecular Immunology. 6th edition. Saunders elsevier; $2009: 35-37$

8. Vincent JL, Zhang J, Sza bo C, Preiser JC. Effect of Nitric Oxide in Septic Shock. Am J Respir Crit Care Med. 2000;16(1):1781-85.

9. Lewis JG. Isolation of Alveolar Macrophages, Peritoneal Macrophages and Kupffer cells. In: methods in immunotoxicology.Vol 2. Editor: Burleson GR, Dean JH, Munson AE. New York. A John Wilye Liss \& sons Inc Publ.1995;15-26.

10. Leijh PCJ, Furh RV, dan Zwet TLV. In Vitro Determination of Phagocyte and Intracellular Killing by Polymorphonuclear and Mononuclear Phagocyte. In: Weir DM Ed, Cellular Immunology. London: Blackwell Scientific Publication; 1986; 46.1- 46.21.

11. Dietert RR, Hotchkiss JH, Austic RE, Sung Y. Production of Reactive Nitrogenc Intermediates by Macrophages. In: Methodes in Immnunotoxicology. Volume 2. editor : Burleson GR, Dean JH, Munson AE. A John Wilye Liss \& sons Inc Publ. New York. 1995; 99-1117

12. Tripathi AK, Kohli S. Phytochemical Screening And Evaluation Of Antidiabetic Activity Of Colocasia Esculenta (L)Leaves On Stz Induced
Diabetic Rats.Adv. Pharmacol. Toxicol. 2013;14 (2):1-12 ISSN - 0973 - 2381

13. Nopitasari DA. Pengaruh Pemberian Ekstrak Buah Phaleria papuana terhadap Aktivitas Fagositosis Makrofag Mencit Balb/C.(Skripsi). Universitas Diponegoro; 2006.

14. Ukhrowi U. Pengaruh Pemberian Ekstrak Etanol Umbi Bidara Upas (Merremia mammosa) terhadap Fagositosis Makrofag dan Produksi Nitrit Oksida (NO) Makrofag Studi pada Mencit Balb/C yang Diinfeksi Salmonella Typhimurium.(Tesis). Universitas Diponegoro; 2011.

15. Baratawidjaja KGB. Iris Rengganis. Imunologi Dasar Edisi Ke 8. Jakarta: Balai Penerbit Fakultas Kedokteran Universitas Indonesia :2009.

16. Susilo J, Erwiyani AR, Awwalia N. Aktivitas Imunomodulator Ekstrak Etanol Daun Jamblang (Syzygium cumini (L) Skeel) Terhadap Respon Imun Non Spesifik Pada Mencit Jantan Galur Balb/c.(Skripsi). STIKES Ngudi Waluyo Ungaran; 2013.

17. Sahat D. Pengaruh Pemberian Ekstrak Hedyotis Corymbosa Dosis Bertingkat terhadap Produksi Nitric Oxide Makrofag Mencit Balb/C yang Diinfeksi Dengan Salmonella typhimurium.(Skripsi).Universitas Diponegoro; 2006

18. Abbas AK, Lichtman AH, Shiv Pillai. Celullar And Molecular Immunology. 6th edition. Saunders elsevier; 2009: 11-16

19. Joefrie GH. Uji Kemanfaatan Ekstrak Etanol Biji Mahoni (Swietenia mahagoni jacq) terhadap Stamina Tubuh Mencit Jantan Strain Balb/C .(Skripsi). Universitas Jember; 2012.

20. Middleton E, Kandaswami C, Theoharides TC. The effects of plant flavonoids on mammalian cells:implications for inflammation, heart disease, and cancer. Pharmacological Reviews. 2000;52 (4): 673-751

21. Mubayinah. Pengaruh Ekstrak Lompong (Colocasia Esculenta L Schoot) 30 Menit Pengukusan Terhadap Aktivitas Fagositosis dan Kadar NO (Nitrit Oksida) pada Mencit Sebelum Dan Sesudah Terinfeksi Listeria monocytogenes.(Draft Skripsi).Universitas Diponegoro; 2015

22. Sholikhah AR. Pengaruh Ekstrak Lompong (Colocasia Esculenta L Schoot) 30 Menit Pengukusan Terhadap Aktivitas Fagositosis dan Kadar NO (Nitrit Oksida) pada Mencit Sebelum Dan Sesudah Terinfeksi Listeria monocytogenes.(Draft Skripsi).Universitas Diponegoro; 2015

23. Abbas AK, Lichtman AH, Shiv Pillai. Celullar And Molecular Immunology. 6th edition. Saunders elsevier; 2009: 311-312

24. Subowo. Imunologi Klinik. Edisi ke-2. Jakarta : Sagung Soto; 2010:413-463. 